\title{
ISLAMIC ECONOMICS AND PARTIAL-TOTAL RELIGIOSITY: A Case Study of Majlis Taklim in Banjarmasin
}

\section{Muhammad Syarif Hidayatullah}

Program Doktor Ilmu Syariah, Universitas Islam Negeri Antasari, Banjarmasin, Indonesia

\section{email: syarif.muhammad849@gmail.com}

\section{ABSTRACT}

In Banjarmasin, most of majlis taklim are dominated by the study of sufism. If there is a discussion of figh (Islamic jurisprudence), it is more inclined about fiqh al'ibadah (figh of worship). Meanwhile figh al-mu'âmalah (fiqh of social interaction) is not a study that is considered important, so that the majlis taklim by the study figh al-mu'amalah are few. Based on participant observation, there are two majlis taklims who carry out da'wa of islamic economics through the study figh almu'âmalah, they are Darul Ma'arif and Ar-Rahmat. Using interactive data analysis, this field research indicates that the two majlis taklims carry out da'wa of islamic economics by presenting fiqh al-mu'âmalah contemporary material through a discussion of mu'âmalah which is associated by economic issues and modern financial. Considering that study fiqh al-mu'âmalah is still few, it is necessary to initiate transformative $d a^{\prime} w a$ as an effort to build a comprehensive Islamic paradigm including worship and social interaction, so that the partial religiousity phenomenon in Banjarmasin become a total religiousity.

\section{ABSTRAK}

Majlis taklim di Kota Banjarmasin didominasi materi pengajian sufism. Jika ada pembahasan fikih, ia lebih cenderung kepada pembahasan fikih ibadah. Sedangkan fikih muamalah tidak menjadi kajian yang dianggap penting, sehingga majlis taklim dengan kajian fikih muamalah (fikih ekonomi syariah) terbatas. Berdasarkan observasi partisipan, ada dua majlis taklim yang melaksanakan dakwah ekonomi syariah melalui pengajian fikih muamalah, yaitu Majlis Taklim Darul Ma'arif dan Majlis Taklim Ar-Rahmat. Penelitian lapangan yang menggunakan analisis data interaktif ini menunjukkan bahwa dua majlis taklim tersebut melaksanakan dakwah ekonomi syariah dengan penyajian materi fikih muamalah kontemporer melalui pembahasan muamalah yang dikaitkan dengan isu-isu ekonomi dan keuangan modern. Karena pengajian fikih muamalah masih sedikit, dakwah transformatif perlu digagas sebagai upaya membangun paradigma Islam komprehensif yang mencakup ibadah dan muamalah, sehingga fenomena religiusitas parsial di Banjarmasin berubah menjadi religiusitas total.
ARTICLE HISTORY

Received 28 April 2020

Accepted 07 June 2020

\section{KEYWORDS}

Majlis taklim; da'wa of islamic economics; figh al-mu'âmalah; partial religiousity; total religiousity 


\section{Introduction}

Islamic law is not limited to matters of worship, because it is broad and comprehensive. In addition to regulate the problem of human servitude to God, it also regulates the issue of interactional relations between human shows the existence of them as social beings. There are signs that limit human behavior to conduct social interactions, including economic and business activities. Islam firmly prevents crime, including in the economic and business world. The responsibility to cultivate businesses that fully implement and institutionalize Islamic values is an important prerequisite for success. ${ }^{1}$ Islam describes, conceptualizes, and structures the rule of law and shows a diverse business, so that it is able to become a guide for economic actors. By paying attention to the signs, they can stay away from things that are forbidden, work, trade, and develop the economy in order to realize the interests and necessities of life fairly. In al-Isrâ' [17]: 12, Allah encourages humans to work to seek sustenance as His gift. ${ }^{2}$

The city of Banjarmasin in South Kalimantan is not only known as the city of a thousand rivers, but is also known as the city of a thousand mosques, because there are many mosques along its streets. In addition, there are also many majlis taklims, both in mosques, and homes, so that the Banjar community is known as a religious community. Islamization in Banjar developed rapidly during the time of Muhammad Arsyad al-Banjarî. He played a major role in the process of Islamization supported politically by the Banjar Sultanate, so Islam became the religion of the majority of Banjar people, even Islam became their identity. ${ }^{3}$

Based on the author's participatory observation in several majlis taklims in the city of Banjarmasin, such as majlis taklim at the Sabilal Muhtadin Grand Mosque, Banjarmasin Sungai Jingah Grand Mosque, Jamik Pemurus Dalam Mosque, At-Taqwa Mosque, and Taklim Bani Ismail KH. Saifuddin Zuhri (Abah Guru of Banjar Indah), the study material in the majlis taklim included three aspects, namely Islamic creed ('aqîlah), Islamic jurisprudence (fiqh), and sufism. However, the learning material is more dominated by morals of sufism or purification of the soul, which is related to the inner aspects and the improvement of morals that are related to good and bad thing. The study of figh is more inclined to fiqh al'sibâdah (fiqh of worship. Whereas figh al-mu'âmalah (figh of social interaction), especially fiqh of Islamic

\footnotetext{
${ }^{1}$ Muhammad Ali Haji Hasyim, Jihad Ekonomi: Kiat Membangun Kekuatan Bisnis Muslimin (Jakarta: Pustaka al-Kautsar, 2005), p. 243.

${ }^{2}$ Mardani, Ayat-ayat dan Hadits Ekonomi Syariah (Jakarta: Rajawali Pers, 2011), p. 5.

${ }^{3}$ Nor Ipansyah, Jalaluddin, and Rahman Helmi, "Fikih Muamalat dalam Majlis Taklim di Kalimantan Selatan," Tashwir, vol. 2, no. 3 (June, 2014): 88.
} 
economics, was not heeded, so that the majlis taklim with fiqh al-mu'âmalah studies was hardly found.

Majlis taklim as a non-governmental organization and a community tool for studying religion still do not pay much attention to the fiqh al-mu'âmalah. Though it is an inseparable part of daily life. Every economic activity is inseparable from the sharia related to legal-vanity (shahîh $\underline{\text { - }}$ bâthil), lawful-forbidden (halâl-harâm), and allowed-not allowed (jâ'iz wa ghair jâ'iz). It shows the urgency of studying and understanding the sharia about mu'âmalah or economic and business activities. In the context of $m u^{\prime}$ âmalah, allowed and forbidden (halâl-harâm) aspects are important to consider. In the aspect of prohibition (harâm), for example, there is something that is unlawful because of the substance (harâm li dzâtihi) and something that is unlawful not because of the substance but because of the way to obtain it (harâm li ghairihi) which is needed to be deeply known so as not to fall into prohibited transactions. Of the several majlis taklims in the city of Banjarmasin, only two majlis taklims study the figh al-mu'âmalah, namely the Darul Ma'arif and the Ar-Rahmat, so it is interesting to be learned.

\section{Method}

The kind of this research is field research with qualitative data collection and interactive Miles and Hubberman's analysis consisting of three concurrent activity streams, namely data reduction, data presentation, and drawing conclusions/verification. ${ }^{4}$

\section{Islamic Economic Concepts and Scopes}

According to Abdullah Zaky al-Kaf, economy is a human need to fulfill, produce, and distribute it. ${ }^{5}$ Islamic economics is simply, according to Asdar, an economy that has been rebuilt on the principles of religiosity and is now oriented. ${ }^{6}$ Conventional economics and Islamic economics differ in looking at welfare; conventional economics views prosperity in the

\footnotetext{
${ }^{4}$ Matthew B. Miles and A. Michael Hubberman, Qualitative Data Analysis: An Expanded Sourcebook (London: SAGE Publications, 1994), p. 10.

${ }^{5}$ Abdullah Zaky al-Kaf, Ekonomi dalam Perspektif Islam (Bandung: Pustaka Setia, 2002), p. 12.

${ }^{6}$ Asdar Yusuf, "Paradigma Kontemporer Ekonomi Islam (Muh. Abdul Mannan versus Syed Nawab Haedir Naqvi)," Hunafa: Jurnal Studia Islamika, vol. 11, no. 2 (December, 2014): 217, https://doi.org/10.24239/jsi.v11i2.355.215-244.
} 
form of self-satisfaction as much as possible, whereas Islamic economics defines welfare as the success of life in the world in carrying out its duties as a caliph to worship Allah Almighty. ${ }^{7}$

Basically, Islamic economics is a metamorphosis of Islamic values in the economy to reject the perception that Islamic law is limited to worship or vertical communication between humans and God. ${ }^{8}$ Islamic economics is built on the basis of five universal values, namely: first, monotheism (tauhîd) as the foundation of Islamic teachings, so that all activities will always be framed within the framework of the faith in God Almighty. Second, justice, which is the application of the principle of not wronging and not being wronged. Third, prophethood, namely the Prophet Muhammad as a role model in the economy. Fourth, the khilâfah (government), the human must maintain harmony in their fellow creatures, so that government must exist to make it happen. Fifth, results, namely motivation in the economy it is not only chasing profits in the world, but also Allah's pleasing. ${ }^{9}$

Islamic economics is a just economy, namely fairness of production, fairness of distribution, and fairness of consumption. The economic crisis can be overcome if the economic concept is Islam, the economic actors are Muslim, and the work culture is Islamic, ${ }^{10}$ because Islam is a blessing for all nature and Islamic economics is an economy full of ethical values, morals, morals, and faith that surrounds it as the process towards prosperity and prosperity. Islamic economics rejects gambling transactions, unclear, illicit substances, usury, and vanity. In Islamic economics, the prevailing theory is economic value of time not time value of money like conventional economics, so that it has implications for the function of money in Islamic economics, which is only a measure of prices and a medium of exchange, not commodities.

The goal of economics is to create a just and prosperous human life, realize prosperity, and erase gaps in Islamic societies through the continuous distribution of wealth with a world and afterlife orientation, so that the Islamic economy has a rabbinical and human economic foundation filled with divine values and is aimed at human prosperity. Islamic economic system contains important aspects that are different from conventional economics, which

\footnotetext{
${ }^{7}$ Agus Irwani, "Epistemologi Hukum Ekonomi Islam (Muamalah)," Religia: Jurnal Ilmu-ilmu Keislaman, vol. 15, no. 1 (April, 2012): 126, https://doi.org/10.28918/religia.v15i1.126.

${ }^{8}$ Muhammad, Prinsip-prinsip Ekonomi Islam (Yogyakarta: Graha Ilmu, 2007), p. 1.

9 Muhammad Syarif Hidayatullah, Perbankan Syariah: Pengenalan Fundamental dan Pengembangan Kontemporer (Banjarbaru: Dreamedia, 2017), pp. 3-4.

${ }^{10}$ Didin Hafidhuddin and Hendri Tanjung, Manajemen Syariah dalam Pratik (Depok: Gema Insani, 2008), p. 72 .
}

39 Islamic Economics and Partial-Total Religiosity| Muhammad Syarif Hidayatullah 
includes the divine dimension on the basis of faith, the legal dimension on the basis of islamic, and the human dimension on the basis of morals.

\section{The object of Fiqh al-Mu'âmalah Study}

The term of mu'âmalah is derived from the word 'âmala-yu'âmilu, which means "to act, act together and practice one another," ${ }^{11}$ while in terminology it is an exchange of things or useful something in a specified manner. ${ }^{12}$ This definition expressed by Rachmat Syafei refers to the definition of mu'âmalah in the narrow sense which directly leads to economic matters. Actually, mu'âmalah in terms can be divided into two senses. In broad terms, mu'âmalah is God's law to regulate people in worldly affairs in social relations, so figh al-mu'âmalah includes all regulations outside of worship, such as marriage, divorce, "iddah, inheritance, politics, crime, and sanctions. ${ }^{13}$ In a narrow sense, $m u^{\prime}$ âmalah is a law of God that regulates human relations with humans related to how to obtain and develop property that must be obeyed, so figh al$m u$ 'âmalah is interpreted as islamic economic law.

\section{Picture 1. Islamic Jurisprudence}

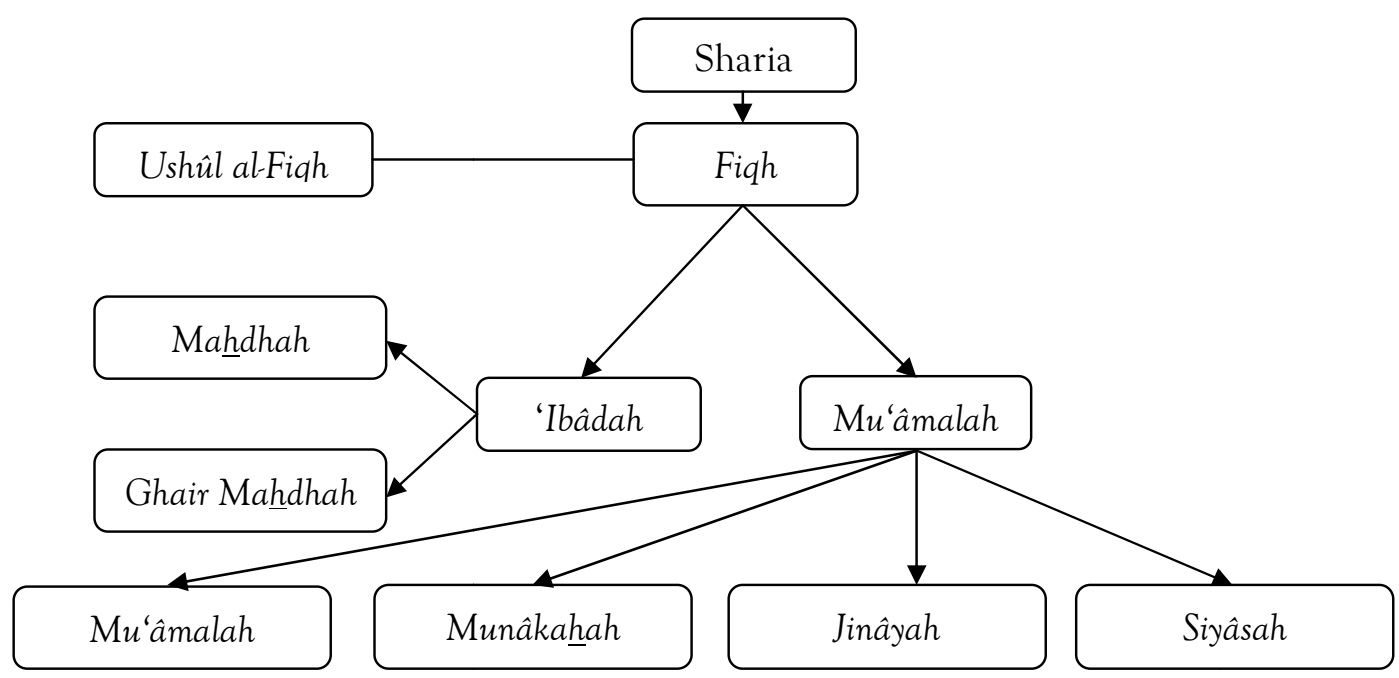

The figh al-mu'âmalah's scope (islamic economic law), namely: first, mu'âmalah mâddîyah, which is a human association relating to material or whose axis is above something material, such as the sale and purchase of goods and services, as well as the exchange of property and

\footnotetext{
${ }^{11}$ Ahmad Warson Munawwir, Kamus Arab-Indonesia (Surabaya: Pustaka Progresif, 1997), p. 1068

${ }^{12}$ Rachmad Syafei, Fiqh Muamalah (Bandung: Pustaka Setia, 2001), p. 14

${ }^{13}$ Wahbah al-Zuhailî, al-Fiqh al-Islâmî wa Adillatuh (Damascus: Dâr al-Fikr, n.d.), p. 19.
} 
benefits between humans through contracts or transactions. ${ }^{14} \mathrm{Mu}$ âmalah mâddîyah includes buying and selling, cooperation, profit sharing, loans, debt, custody, rent, wages, money exchanges, competitions, service agreements, philanthropy, and contemporary economic problems, such as Islamic banks, Islamic cooperatives, islamic insurance, sharia capital markets, e-commerce, e-money, and e-wallet. Second, mu'âmalah adabîyah, which is interpersonal relations with the emphasis on behavior, attitudes, and actions that originate from the mouth and limbs, which are basically politeness and civilization so that civil society can be created. ${ }^{15} \mathrm{Mu}$ 'amalah adabîyah includes consent granted, pleasure, justice, honesty, elements of fraud, hoarding, and forgery.

The jurisprudence applies in the case of mu'âmalah is "al-ashl fî al-mu'âmalât al-ibâhahah illâ an yadull dalîl' alâa tahrîmihâ" (the original law of mu'âmalah is permissible, unless there is an argument that forbids it). Therefore, ijtihâd and innovation are required. Ijtihâd must not stop so that all questions and rules of Islam are revealed, because Islamic law governs all business and finance in every space and time. ${ }^{16}$

\section{The Fiqh al-Mu âmalah Study at the Majlis Taklim in Banjarmasin City}

Islam is a religion of missionary $\left(d a^{\prime} w a\right)$, namely it is calling and invitation to conversion, or an effort to change the situation to be better and more perfect, both for individuals and the community. In an integralistic sense, $d a^{\prime} w a$ is a continuous process handled by the $d a^{\text {'wa }}$ bearers to change the target of it so that they are willing to enter the path of Allah and gradually towards the path of Islamic life. ${ }^{17} d a$ 'wa material as indicated by the Qur'an revolves around three main problems, namely creed, morals, and law. The essence of da'wa is inviting good deeds (khair) with commanding right and forbidding wrong (al-amr bi al-ma'rûf wa al-nahy 'an al-munkar) which are based on wisdom and good advice (mau'izhah hasanah), namely strict and true speech that can distinguish between rights and vanity accompanied by goodness (hasanah). ${ }^{18}$

\footnotetext{
14 'Alî Fikrî, al-Mu'âmalât al-Mâddîyah wa al-Adabîyah (Cairo: Musthafâ al-Bâbî al-Halabî, 1939), p. 7.

${ }^{15}$ Ibid., p. 9.

${ }^{16}$ Oni Sahroni, Fikih Muamalah Kontemporer (Jakarta: Republik, 2019), pp. 282-3.

${ }^{17}$ Didin Hafiduddin, Dakwah Aktual (Jakarta: Gema Insani Press, 2000), p. 77.

${ }^{18}$ Atang Abd. Hakim, Fikih Perbankan Syariah: Transformasi Fikih Muamalah ke dalam Peraturan Perundangundangan (Bandung: Refika Aditama, 2011), pp. xii-xiii.
} 
Majlis taklim became one of the da'wa facility attracted the general public and reached all groups, including students, practitioners, academics, and officials, like seminars, workshops and training. The development of Islamic economics in Indonesia has influenced the existence of its education forums, such as workshops, training, short courses, and seminars. However, these forums' scope is still limited for practitioners and campus academics, while the general public is still not evenly touched. Thus, the majlis taklim, as a forum to demand religious knowledge grounded in the community, becomes an educational media that can reach the general public to increase islamic economic and financial literacy. Therefore, fiqh al-mu'âmalah is important to see the current economic development while still observing the transactions made, between legal-vanity (shah ĥh h-bâthil), lawful-forbidden (halâl-harâm), and allowed-not allowed (jâ'iz wa ghair jâ'iz). Moreover, the concepts of contemporary financial products under modification, creation, and innovation.

\section{Trends in Study Material at Majlis Taklim in Banjarmasin City}

Although the recitation materials of the majlis taklim in the city of Banjarmasin are dominated by sufism, but the material of tauhîd and figh also exists. but the material of figh is dominated by fiqh al'ibâdah, while fiqh al-mu'âmalah is less desirable and less attention, both by scholars and the public. Moreover, contemporary fiqh al-mu'âmalah has emerged as a contemporary issue, such as contemporary financial products that are present in the midst of today's economic society, influenced by the times, advances in information technology, the economy, dynamic business, and increasingly complex community needs.

In Banjarmasin, some charismatic master teachers (ulemas) have hundreds or even thousands of worshipers in their majlis taklim. The majlis taklim which was attended by many congregations and attracted the people of Banjarmasin was the sample of this study, which showed the style of recitation in Banjarmasin.

Tabel 1. Study Material at Majlis Taklim in Banjarmasin City

\begin{tabular}{|c|c|c|}
\hline Majlis Taklim & Subject & Focus \\
\hline $\begin{array}{c}\text { KH. Ahmad Zuhdiannor } \\
\text { (Abah Haji Guru Zuhdi) }\end{array}$ & $\begin{array}{c}\text { Kitab Sifat 20 by Habib Utsman bin } \\
\text { Yahya }\end{array}$ & Faith \\
\hline & $\begin{array}{c}\text { Hidâyah al-Sâlikin by 'Abd al-Shamad } \\
\text { al-Falimbânî }\end{array}$ & $\begin{array}{c}\text { Faith, Figh, and } \\
\text { Sufism }\end{array}$ \\
\hline
\end{tabular}




\begin{tabular}{|c|c|c|}
\hline & $\begin{array}{c}\text { Al'Ilm al-Nibrâs by al-Habîb 'Abd } \\
\text { Allâh ibn 'Alwî ibn } \underline{\text { Hasan al- }} \\
\text { 'Aththâs }\end{array}$ & Sufism \\
\hline & Ihya' 'Ulûm al-Dîn by al-Ghazâlî & Sufism \\
\hline & Syarh al- $\underline{H}$ ikam by Ibn Athâ' Allâh & Sufism \\
\hline \multirow{2}{*}{$\begin{array}{l}\text { KH. Saifuddin Zuhri (Abah } \\
\text { Guru Banjar Indah) } \\
\end{array}$} & Minhâj al-ÂAbidin by al-Ghazâlî & Sufism \\
\hline & $\begin{array}{c}\text { Al-Anwâr al-Muhammadîyah by Yûsuf } \\
\text { ibn 'Ismâ'îl al-Nabhânî }\end{array}$ & Prophetic biography \\
\hline \multirow[t]{4}{*}{ KH. Ilham Humaidi } & $\begin{array}{l}\text { Al-Nashâ' ih al-Dînîyah by 'Abd Allâh } \\
\text { 'Alwî al-Haddâd }\end{array}$ & Sufism \\
\hline & $\begin{array}{c}\text { Marâqî̀ } \\
\text { 'Ubûdîyah by Muhammad Nawawî al- } \\
\text { Bantanî al-Jâwî }\end{array}$ & Fiqh and Sufism \\
\hline & Bidâyah al-Hidâyah by al-Ghazâlî & Fiqh and Sufism \\
\hline & 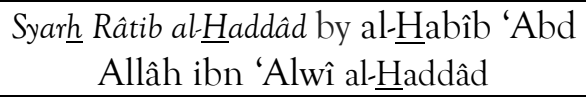 & Sufism \\
\hline
\end{tabular}

\section{The Study of Fiqh al-Mu'âmalah at the Majlis Taklim Darul Ma'arif}

Darul Ma'arif studied fiqh al-mu'âmalah which was raised by Ustaz Wahyudi Ibnu Yusuf. In addition to being busy preaching and caring for the majlis taklim, Yusuf is also completing his dissertation on Islamic financial and financial fatwas from Dewan Syariah Nasional Majelis Ulama Indonesia/the National Sharia Council of the Indonesian Ulema Council (DSN-MUI) at the Antasari State Islamic University, Banjarmasin. The study of fiqh al-mu'âmalah in Darul Ma'arif is held once a week on Tuesday at 16.30 to 18.00 by studying al-Mu'tamad fî al-Fiqh alSyâfi î̀ volume III by Muhammad al-Zuhailî. Aside from going through majors, Yusuf also preached about islamic economics in the study of fiqh al-mu'âmalah via WhatsApp Group and Youtube on the Ma'had Darul Ma'arif channel with a thematic-systematic study of contemporary figh al-mu'âmalah based on Harta Haram Muamalat Kontemporer by Erwandi Tarmidzi, Dirâsah fî al -Fiqh al-Islâmî by Muhammad Husain 'Abd Allâh, and Nizhâm al-Iqtishâd fî al-Islâm by Taqîy al-Dîn al-Nabhânî.

The recitation has been running for half a year. In fact, in the beginning, the study of al$M u$ 'tamad began with the fiqh al'ibâdah, because this book did not specifically address mu'âmalah. Discussion of this book includes: cleanse, prayer, and corpse (volume I); almsgiving, fasting, pilgrimage to Mecca, 'ubûdîyah (volume II); financial transactions and contracts (volume III); family law (volume IV); and jihâd, 'uqûubât, and qadhâ' (volume V). So after volume 
I is finished, Yusuf goes straight to the discussion of volume III about mu'âmalah, because $m u^{\prime}$ ammalah is a point that must be directed immediately so that the practice is in accordance with the principles of islamic. The practice of usury and transactions that are contrary to the principles of Islam are the object of Yusuf's attention, so that Muslims do not get caught up in usury transactions. Moreover, the various types of financial products today that have emerged, so that Muslims must be able to sort out in order to be able to interact in accordance with the rules of Islamic law in everyday life.

Yusuf chose al-Mu'tamad in his study for three main reasons, namely: first, lay people (beginners) need to be introduced to one school first or not directly introduced to comparative Islamic jurisprudence studies, because it can confuse them. Second, the Syafi'i school of thought was chosen, because the Syafi'i school is the school of the majority of the population in Indonesia, especially in Banjarmasin. Third, from many Shafi'i schools, al-Mu'tamad was chosen because he collected various opinions that were either recognized (mu'tamad) or strong (râjih from various opinions that were marginal (marjûh $)$. In fact, many of the Shafi'i schools are authoritative (mu'tabar) and contain opinions that are recognized (mu'tamad), but the points are spread in several books. Al-Mu'tamad accommodates various recognized opinions in the Syafi'i schools which are spread throughout many of these books. ${ }^{19}$

Al-Mu'tamad is one of the Syafi'i schools of figh. It is the work of Muhammad al-Zuhailî, the younger brother of Wahbah al-Zuhailî, a Syrian scholar and the author of al-Figh al-Islâmî wa Adillatuh. Al-Mu'tamad fî al-Fiqh al-Syafi'î means the Syafi'i school of fiqh guidelines which are recognized and sourced from primary references, and contain explanations that are valid and agreed upon by the ulemas of the Syafi'i school of figh. This book is suitable to be used as a guide for Indonesian Muslims in studying the Syafi'i school of fiqh which is recognized by scholars and experts of Syafi'i school of fiqh.

Al-Mu'tamad volume III delivered by Yusuf in the study of figh al-mu'âmalah at the Darul Ma'arif contained fiqh al-mu'âmalah material, namely buying and selling, rent, wages, grants, money loans, pawning, peace, debt transfer, competition, rights for joint ownership, loan for goods, partnership, profit sharing, safekeeping, finding, underwriting, representation, taking other people's property rights, cooperation in managing plantations, agricultural cooperation,

${ }^{19}$ Wahyudi Ibnu Yusuf, the head of Darul Ma'arif, Interview, 27 April 2020. 
endowments, livelihood of dead land, confiscation, bankruptcy, child discovery/collection, competition, and archery.

Sufism study material is the dominant study material in Banjarmasin. This can be seen from the data of study objects in large majlis taklims attended by hundreds to thousands of worshipers in table 1 above showing the religious religiosity of the Banjar people who are sufistic, so that figh al-mu'âmalah is less noticed. This contrasts with Yusuf's experience in his preaching. Based on his confession, the congregation turned out to be more enthusiastic in attending the fiqh al-mu'âmalah study; many reciters of the congregation asked questions. They are passionate about learning and want to know a lot about mu'âmalah. This was not felt when studying the fiqh al'ibâdah as initial material in the study of the al-Mu'tamad. ${ }^{20}$

They appreciated Yusuf's fiqh al-mu'âmalah discussion and felt the urgency of it. Related to this, Abdul Jabar, a congregation of majlis taklim, said:

"I am very happy to be able to attend the figh al-mu'âmalah recitation with him. This is very important because it is related to our daily activities." 21

In addition, Yusuf's fiqh al-mu'âmalah study adds to religious knowledge and calms the heart, because it can interact each other and seek fortune according to Islamic law, as revealed by Masudi Suhaib, a congregation of majlis taklim, as follows: ${ }^{22}$

"Yusuf's figh al-mu'âmalah study is very good and it is needed by the people to improve the way to interact each other in order to get a living fortune that is thayyiban. After following Yusuf's figh al-mu'âmalah, my feelings become calmer and I can interact with syarî̀ science."

Al-Mu'tamad is indeed a Syafi'i school of figh, but in the study of figh al-mu'âmalah, Yusuf conveys the contents of this book as the main study material and at a glance expresses different schools of opinion if there are differences of opinion among scholars regarding a khilâfìah case, as expressed Bahraini Iberahim, a congregation of majlis taklim, as follows: ${ }^{23}$

"The figh al-mu'âmalah study which was delivered by Ustaz Wahyudi Ibn Yusuf in his majlis taklim was very good to follow, because it directly used the recognized book in the Imam Syafi'i school of fiqh, namely al-Mu'tamad fî al-Fiqh al-Syafi î in volume III of mu'âmalah. His delivery was quite clear and easy to understand. He is not only focused on the book. Sometimes he also gives a difference of opinion among the Muslim scholars, so that it further clarifies the material being studied."

\footnotetext{
20 Ibid.

${ }^{21}$ Abdul Jabar, a congregation of Darul Ma'arif, Interview, 14 May 2020.

${ }^{22}$ Masudi Suhaib, a congregation of Darul Ma'arif, Interview, 14 May 2020.

${ }^{23}$ Bahraini Iberahim, a congregation of Darul Ma'arif, Interview, 14 May 2020.
} 
In his figh al-mu'âmalah study, Yusuf was not limited to the concept of classical figh. Although al-Mu'tamad contains discussions that tend to the concept of classical financial transactions, but in his presentation, Yusuf tried to relate the text of the book to the present context, because there are many things related to economics and modern financial transactions that did not exist in ancient times, so it is not listed firmly in classical fiqh and the discussion needs to be correlated with contemporary case studies. Therefore, Yusuf conveyed it to the congregation by adding discussion on economic fatwas and islamic finance issued by Dewan Syariah Nasional Majelis Ulama Indonesia/the National Sharia Council of the Indonesian Ulema Council (DSN-MUI), islamic banking products, and other contemporary financial transactions.

\section{Fiqh al-Mu'âmalah Recitation at the Ar-Rahmat}

Ar-Rahmat studies figh al-mu'âmalah under the care of Ustaz Muhammad Hasbi Ridhani. The majlis taklim is held routinely every morning on Sunday, at 08.30 to 10.00 . The study in the majlis taklim is not limited to the problem of mu'amalah and the speaker is not only Ridhani, but the speaker and the material is different every week. In addition to fiqh almu'âmalah, this majlis taklim also examines family fiqh (munâkahâat or ahwâl syakhshîyah), interpretation of the Qur'an, and commentary of the hadith.

In addition to preaching through the majlis taklim, Ridhani also preached digitally by Youtube in the form of video content preaching figh al-mu'âmalah on the Rifqan TV channel with contemporary mu'âmalah studies. Aside from being a preacher, he is also a Islamic Supervisory Board at the Arrahmah Syariah Cooperative which has four offices namely in Banjarmasin, Martapura, Barabai, and Kotabaru. So, apart from being a preacher who takes care of figh al-mu'âmalah studies, he is in direct contact with the practices of Islamic financial institutions that monitor the application of islamic principles in product operations both fund raising and fund distribution and services, which are carried out by the Arrahmah Syariah Cooperative.

The existence of Arrahmah Syariah Cooperative is inseparable from the majlis taklim ArRahmat, because the idea of its establishment originated from the study of figh al-mu'âmalah in the majlis taklim. The idea arose through the dialogue of the leaders in the majlis taklim who wanted figh al-mu'âmalah not to stop at the level of recitation, but could be realized in daily 
practice. In addition, this is because it is concerned about the practice of usury that is rampant in the community. Even Muslims seem to underestimate the sin of usury, even though the usurer is threatened to be fought by Allah and His messenger (Al-Baqarah [2]: 279). With an anti-usury transaction spirit and high hopes for the facilitators to be able to apply the values of figh al-mu'âmalah in real life to help the community not to be caught in the usury trap, they then established a islamic cooperative. ${ }^{24}$

Ridhani began to focus on the study of figh al-mu'âmalah in the last four years. The trigger factors for studying financial transactions (mu'âmalah mâlîyah) are as follows: first, the study of this mu'âmalah is rarely touched, because most of the things studied are matters of worship, creed, and soul purification. If there is someone who offends mu'âmalah, but only convey it in general without delving into the core problem. Second, concern over the transactions of some Muslims who are inseparable from the practice of usury. The practice of usury has taken over, even some of them eventually fall into the transaction usury to simply meet the needs of food. ${ }^{25}$

Ridhani's study of figh al-mu'âmalah is more flexible. He uses book studies as well as thematic studies with contemporary lecture and case study methods. The recitation of the recitation comes from the Qur'an, sunnah, and the thought and ijtihâd of classical and contemporary scholars. Among his reference books are Taudhîh al-Ahkâm min Bulûgh al-Marâm by 'Abd Allâh ibn 'Abd al-Raḩmân al-Bassâm, Shaĥh $\underline{h}$ Fiqh al-Sunnah by Abû Mâlik Kamâl ibn alSayyid Sâlim, the book by Sulaimân al-Ruhailî, Harta Haram Muamalat Kontemporer by ErwandiTarmidzi, Riba dan Tinjauan Kritis Perbankan Syariah and Fikih Perniagaan Nabi saw. by M. Arifin Baderi, Ada Apa dengan Riba?, Pengantar Fiqih Jual Beli, Pengantar Permodalan dalam Islam, Kode Etik Pengusaha Muslim, Ada Orang Utang, and Pasar Muslim $\mathcal{E}$ Dunia Makelar by Ammi Nur Baits. ${ }^{26}$

In his study, Ridhani responded and responded critically to the modern economy which tended to ignore sharia, especially for Muslims who should understand sharia not only on the aspect of worship, but also on the aspects of mu'âmalah. The reality on the ground shows the ignorance of some Muslims in watching the contemporary economy which only looks at its profit, not paying attention to its rules and regulations. Neglectful attitude towards fiqh almu'âmalah finally brought down Muslims on illicit transactions, such as usury, obscurity, and

\footnotetext{
${ }^{24}$ Athif Raihan, a manager of Koperasi Syariah Arrahmah and a congregation of Ar-Rahmat, Interview.

${ }^{25}$ Muhammad Hasbi Ridhani, a tutor of fiqh al-mu'âmalah in Ar-Rahmat, Interview, 13 May 2020.

${ }^{26}$ Ibid.
} 
gambling. In his study, Ridhani not only explained the classic transaction, but also tried to explain examples of contemporary muamalah cases. The study material includes debt ethics, usury, obscurity, entrusted services, lottery prizes, Multi Level Marketing (MLM), Home Ownership Loans (KPR), credit cards, and fiqh of GoFood \& GoPay.

Bram Rizkan Suryo Ramadhan, a congregation of majlis taklim, appreciated Ridhani's discussion about figh al-mu'âmalah and felt the urgency of figh al-mu'âmalah to be studied. He stated,

"So, after I took his recitation, I think the public should have attended many mu'âmalah studies, because that was very important, right? So also after attending his study, I know about mu'âmalah problems that I did not know before and many of my sexual habits that turned out to be incompatible with Islamic law, which I found out after following his study." ${ }^{27}$

Ridhani tried to explore mu'âmalah problems from normative sources. Then relate it to the socio-economic reality in actual interactions today, as stated by Athif Raihan, a congregation of majlis taklim, as follows:

"Good and easy to understand, because in addition to reading the book also given its implications through the case of the case. After participating in the study, I understand to solve the mu'âmalah problems in daily life." ${ }^{28}$

Ridhani's mu'âmalah study is not only on the theoretical-conceptual scope of classical economics, but also responds to the development of financial transactions with contemporary economic studies. In the discussion of the sale and purchase agreement, for example, he was not limited to conveying the basic concept, but expanded it with the study of Home Ownership Loans (KPR), buying and selling online, resellers, and dropshippers. In the discussion of debt and usury, he related it to the practice of interest in money in financial institutions, including Islamic financial institutions that still did not really apply the principles of sharia. On the issue of rent and wages, the study is not only limited to the pillars and conditions, but also includes the study of online motorcycle taxi services and other forms of contemporary services.

Discussions that respond to the times and present social reality can help economic actors, including entrepreneurs, to do business according to Islamic law. Rizky Cipta Anugerah, a congregation of majlis taklim and an entrepreneur, revealed the benefits as follows: ${ }^{29}$

\footnotetext{
${ }^{27}$ Bram Rizkan Suryo Ramadhan, a congregation of Ar-Rahmat, Interview, 13 May 2020.

${ }^{28}$ Athif Raihan, a congregation of Ar-Rahmat, Interview, 13 May 2020.

${ }^{29}$ Rizky Cipta Anugerah, a congregation of Ar-Rahmat and an entrepreneur, Interview, 13 May 2020.
} 
"In my opinion, it is good, so that we are as entrepreneurs or prospective entrepreneurs are able to know about mu'âmalah studies, knowledge, and signs so that our efforts do not violate Islamic law."

\section{From Partial Recigiosity Towards Total Religiosity}

According to Muhammad Syafi'i Antonio, Islam is often misunderstood as a religious religion, not as a comprehensive system that covers all aspects of life, including economics. This is a wrong view, because Islam as a comprehensive and universal teaching contains understanding as the sharia which regulates and summarizes all aspects of life, both worship (ritual) and mu'âmalah (social interaction). Worship is needed to maintain the obedience and harmony of human relations with God Almighty. Worship is also a means of reminding man's duty as khalifah on earth. While mu'âmalah is the rule of the human game in the relationship between people in their lives as social beings. ${ }^{30}$

The perception of Islam as a religion that regulates rituals and does not play an active role in economic development makes Muslims begin to forget the figh al-mu'âmalah. Sufism in the form of purification of the soul and the study of fiqh al'ibâdah become the main study, but on the other hand figh al-mu'amalah is only a makeshift study. Misperception about the economy in Islamic teachings ultimately makes some Muslims close their eyes and do not care about the economic activities carried out, in accordance with or not in accordance with the principles of Islamic.

'Umar ibn al-Khaththâb had ordered: "Let no one sell in our market, unless he has understood the science of religion!” This order shows the urgency of understanding about religious knowledge related to mu'âmalah, because financial transactions between producers and consumers occur in the market which is an economic sector. Abû al-Laits said, "An illegitimate man makes a sale and purchase agreement while he has not mastered the

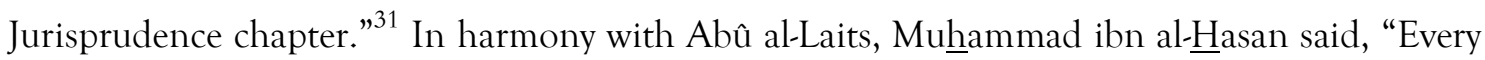
trader who holds a strong religion must ask to be accompanied by figh al-mu'âmalah experts who are cautious so that the merchant can consult with the fiqh expert about the transactions made. $^{32}$

\footnotetext{
${ }^{30}$ M. Arfin Hamid, Membumikan Ekonomi Syariah di Indonesia: Perspektif Sosioyuridis (Jakarta: eLSAS, 2008),
} p. 306.

${ }^{31}$ Aḥmad ibn Muhammad ibn Muhammad Abû al-Walîd Lisân al-Dîn ibn al-Syihnah al-Tsaqafî al- $\underline{\text { Halabî, }}$

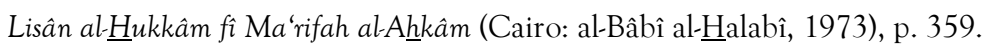

${ }^{32}$ Ibid. 
The statements of 'Umar, Abû al-Laits, and Ibn al- Hasan show the urgency of learning and understanding mu'âmalah rules related to economic and business activities. However, a halfhearted attitude towards figh al-mu'âmalah has an impact on the attitude of indifference to the lawful and forbidden or legitimate and vanity status related to financial transactions carried out. Even though they are inseparable from economic activities every day, giving rise to the phenomenon of partial religiosity in the midst of society, because they improve worship and the mind optimally, but improve mu'âmalah minimally.

On one hand, the mosque is prospered with congregational prayers, i'tikâf, ifthâr together, and the majlis taklim, but on the other hand the practice of usury is increasingly widespread everywhere. The practice of usury appears to be a forbidden element considered normally in the community, whether channeled individually such as moneylenders or institutionally disbursed such as the usury financial institutions operating with interest-bearing loans. Even with the offer of ease and speed of access in the form of the slogan "one-hour service" increasingly makes people tempted to do usury debts. Whereas usury is a forbidden activity and a big sin that should not be underestimated (al-Baqarah [2]: 279). Ibn Mâjah narrates a hadith from Abû Hurairah about the sin of usury as follows: ${ }^{33}$

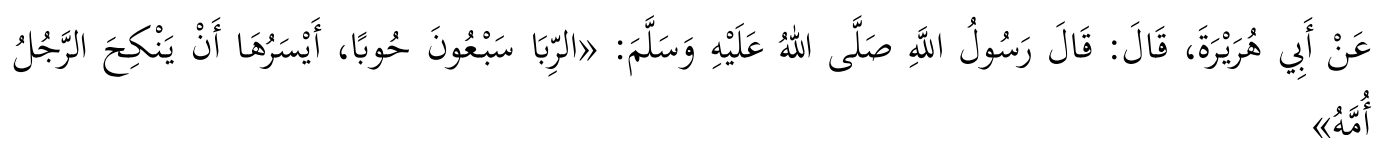

Narrated by Abû Hurairah, he said, "The messenger PBUH of Allah said, 'Usury is seventy sins. The lightest $\sin$ is (the same as) the sin of the person who commits adultery with his mother."

In Islamic economic law or fiqh al-mu'âmalah, fiqh rules that form the basis of general mu'âmalah activities are "al-ashl fî al-mu'âmalât alibâhaha illâ an yadull dalîl' alâa tahrîmihâ" (the original law of mu'amalah is permissible, unless there is an argument that forbids it). ${ }^{34}$ Therefore, it is important to identify economic activities as follows. Forbidden categories can be classified into two types, namely harâm li dzâtihi and harâm li ghairihi. Harâm li dzâtihi is anything that is forbidden by the substance or because it is forbidden, while harâm li ghairihi is not forbidden because of its substance, but forbidden because of other things that make it

\footnotetext{
${ }^{33}$ Abû 'Abd Allâh Muhammad ibn Yazîd al-Qazwinî ibn Mâjah, Sunan Ibn Mâjah, vol. III (Beirut: Dâr alKutub al-'Ilmîyah, 2012), p. 80.

${ }^{34}$ Fathurrahman Azhari, Qawaid Fiqhiyyah Muamalah (Banjarmasin: Lembaga Pengembangan Kualitas Ummat Banjarmasin, 2014), p. 156.
} 
unclean, such as how to get it. Examples of harâm li ghairihi in matters of economic and financial transactions are fadl and nasî'ah usury, obscurity, gambling, buying and selling fraud, hoarding, fraud, and bribery. ${ }^{35}$

Based on the basic rules of mu'âmalah before, the opportunity for innovation in economic and financial products that do not conflict with Islamic law is still open. Agus Rijal generally mentions prohibitions in mu'âmalah, which among them are: ${ }^{36}$ first, illicit commodities and businesses that lead to disobedience. Second, maysir, namely ownership of assets without a contract that is permitted or through play. Third, gharar, which uses the contract, but is unclear or hides the facts. Fourth, usury, which is an additional who wronged. Fifth, bai' mudhtharr, which is to play the price when others need it. Sixth, ikrâh, which is to play the price with pressure or coercion. Seventh, ghabn fâhisy, which is to raise prices out of the ordinary. Eighth, najsy, which is toying with prices by pretending or using another party as a bidder. Ninth, ihtikâr, playing the price by hoarding. Tenth, ghisysy, which is hiding information about goods or services with the intention of keeping prices. Eleventh, tadlis, which is to take advantage by mixing good goods with bad ones.

Allah ordered us to enter Islam in totality, not partially (al-Baqarah [2]: 208). The phenomenon of partial religiosity must evolve into total religiosity with aspects of Islam that touch the issue of worship and mu'âmalah. If it continues, the sin of usury will be increasingly considered normal, the practice of flowering money is increasingly rampant, and the usury financial institutions are increasingly growing in society, while Islamic financial institutions will gradually be eliminated because of the skeptical attitude of Muslims themselves. The existence of Islamic financial institutions which in essence is to prevent the public from the practice of usury will be eroded by skeptical attitudes of Muslims who prefer usury financial institutions. This will also have implications for Islamic financial institutions which are starting to fade their islamic side in order to be able to compete with usury financial institutions. Whereas if there are irregularities in the practice of Islamic financial institutions, then what needs to be done is to fix them, not just leave them, then choose the usury financial institutions.

Allah ordered us to enter Islam in totality, not partially (al-Baqarah [2]: 208). The phenomenon of partial religiosity must evolve into total religiosity with aspects of Islam that

\footnotetext{
${ }^{35}$ Hidayatullah, Perbankan Syariah, p. 9-23.

${ }^{36}$ Agus Rijal, Utang Halal Utang Haram (Jakarta: Gramedia Pustaka Utama, 2013), pp. 44-5.
} 
touch the issue of worship and mu'âmalah. If it continues, the sin of usury will be increasingly considered normal, the practice of flowering money is increasingly rampant, and the usury financial institutions are increasingly growing in society, while Islamic financial institutions will gradually be eliminated because of the skeptical attitude of Muslims themselves. The existence of Islamic financial institutions which in essence is to prevent the public from the practice of usury will be eroded by skeptical attitudes of Muslims who prefer usury financial institutions. This will also have implications for Islamic financial institutions which are starting to fade their islamic side in order to be able to compete with usury financial institutions. Whereas if there are irregularities in the practice of Islamic financial institutions, then what needs to be done is to fix them, not just leave them, then choose the usury financial institutions.

During the preaching of the Prophet Muhammad PBUH, the application of the value and actual application of Islamic economics was highly considered, because Mecca was the largest trading area at that time. Great attention to economic problems is a preventive measure against various frauds in economic activity. Hadith about mu'âmalah and state management are numerous. ${ }^{37}$ Therefore, the idea of transformative $d a^{6} w a$ as an effort to build a comprehensive Islamic paradigm needs to be expressed. Transformative da'wa has several indicators that must be met. Three of these indicators are: first, in terms of $d a^{\text {'w } w a ~ m a t e r i a l, ~ t h e r e ~ i s ~ a ~ m e a n i n g f u l ~}$ transformation from the extent of the study of worship expanded to the discussion of social issues. Second, in terms of methodology, the transformation of the monologue model into dialogue. Third, use institutions that can synergize in the $d a^{\prime} w a$ process. ${ }^{38}$

First, in terms of da'wa material, that is, the transformation from a study of worship is extended to a dynamic study of the present that responds to social issues, including contemporary mu'âmalah. It also continues from exclusive preaching to inclusive material. Several books can be used as reference for the study of books in the majlis taklim on Islamic economic issues with the study of fiqh al-mu'âmalah, both classical and contemporary, namely alMu'tamad fî al-Fiqh al-Syâfi'î by Muhammad al-Zuhailî, al-Mu'âmalât al-Mâlîyah al-Mu'âshirah by Wahbah al-Zuhailî, al-Mu'âmalât al-Mâlîyah al-Mu'âshirah fî al-Fiqh al-Islâmî by Muhammad 'Utsmân Syibair, Fawâ'id al-Bunûk hiya al-Ribâ al-Harâm by Yûsuf al-Qardhâwî, Fiqh al-Mu'âmalât

\footnotetext{
37 Sri Anafarhanah, "Peran Ekonomi Islam dalam Dakwah Nabi Muhammad saw.," Alhadharah: Jurnal Ilmu Dakwah, vol. 14, no. 28 (December, 2015): 9, http://dx.doi.org/10.18592/alhadharah.v14i28.1230.

38 Siti Hasanah, "Inovasi Materi Dakwah dari Ibadah ke Muamalah Bagi Ormas Islam untuk Merealisasikan Masyarakat Inklusif di Kota Semarang,” Jurnal Dakwah, vol. 15, no. 2 (2014): 320-321, https://doi.org/10.14421/jd.2014.15205.
} 
al-Mâlîyah by Rafiq Yûnus al-Mishrî, al-Mu'âmalâh al-Mâlîyah by Sa'd al-Dîn Muhammad alQibthî, Buhn̂ts fî Fiqh al-Mu'âmalât al-Mâlîyah al-Mu'âshirah by 'Alî Muhyî al-Dîn, Fiqh alMu'awadhah by Musthafâ Dîb al-Bughâ, al'Uqû̉d al-Murakkabah fî al-Fiqh al-Islâmî by Nâzih Hammâd, and al'‘Uqûd al-Musammâh by Musthafâ al-Zarqâ.

Second, in terms of methodology, namely the transformation of monologues into dialogue in da'wa through recitation at the majlis taklim. In each study, both book studies and thematic studies, there are questions and answers after the material is delivered to provide a qualified understanding to the congregation. Question and answer session describes dialogue between preachers (subjects of $d a^{\prime} w a$ ) and congregations (objects of $\left.d a^{\prime} w a\right)$, which can clarify the material of $d a^{\prime} w a$ and maximize the media of $d a^{\prime} w a$ with the method of $d a^{\prime} w a$ that embodies a dialogue climate in the form of two-way communication. This is done so that things that are still unclear or not understood by the congregation can be answered and can prevent errors and misunderstandings in absorbing study material.

Third, use institutions that can synergize in the process of da'wa. Islamic economic propaganda at majlis taklim can work together with Islamic economic fatwa institutions namely Dewan Syariah Nasional Majelis Ulama Indonesia/the National Sharia Council of the Indonesian Ulema Council (DSN-MUI) and Islamic economic movement organizations, such as Masyarakat Ekonomi Syariah (MES), Ikatan Ahli Ekonomi Islam (IAEI), Komite Nasional Ekonomi dan Keuangan Syariah (KNEKS), Forum Dosen Ekonomi dan Bisnsi Islam (FORDEBI), Forum Silaturrahim Studi Ekonomi Islam (FOSSEI), Asosiasi Bank Syariah Indonesia (ASBISINDO), Asosiasi Koperasi Syariah Indonesia (ASYKINDO), Komunitas Pengusaha Muslim Indonesia (KPMI), and Masyarakat Tanpa Riba (MTR).

Knowledge and understanding become fundamental provisions in the process of grounding the Islamic economy. The development of knowledge and inculcation of understanding is the first step towards efforts to ground the Islamic economy. One popular approach is to maximize the role of the majlis taklim as a means of preaching Islamic economics through the study of figh al-mu'âmalah, especially those in contact with modern economics. Therefore. Efforts to popularize the Islamic economy and make the economy economical are a form of actualizing Islamic economic of jihad. 


\section{Conclusion}

The study at majlis taklim in Banjarmasin was dominated by sufism material. In addition to sufism material, tauhîd and fiqh material were also examined. The material of figh is dominated by fiqh al-ibâdah, while fiqh al-mu'âmalah is less desirable, so that some Muslims begin to close their eyes and foster ignorance of economic activities undertaken, in accordance with or not in accordance with Islamic law. It shows the phenomenon of partial religiosity in the midst of society, namely trying to improve a worship and purification of the soul optimally, but trying to improve mu'âmalah minimally. Therefore, the actualization of transformative preaching is necessary.

The implementation of Islamic economic da'wa by fiqh al-mu'âmalah study in two majlis taklims, namely the Darul Ma'arif and the Ar-Rahmat, shows that both majlis taklims together present fiqh al-mu'âmalah material with discussion that is not limited to economic and financial concepts classic, but also presents contemporary economic and financial studies in response to the situation and conditions of the modern economy. So the material substance does not only describe the form, harmony, and requirements of the islamic agreements, but has penetrated the case studies and diverse contemporary financial products in the community. In addition, two preachers also took a part in their $d a^{\prime} w a$ based on digital in preaching about the Islamic economics by Youtube video content.

\section{References}

Al-Kaf, Abdullah Zaky. 2002. Ekonomi dalam Perspektif Islam. Bandung: Pustaka Setia.

Anafarhanah, Sri. 2015. "Peran Ekonomi Islam dalam Dakwah Nabi Muhammad saw," $\begin{array}{llllll}\text { Alhadharah: Jurnal Ilmu Dakwah, } & 14 & \text { (28): } & \text { 1-17, }\end{array}$ http://dx.doi.org/10.18592/alhadharah.v14i28.1230.

Anshari, Hafi. 1993. Pemahaman dan Pengalaman Dakwah (Pedoman Mujtahid Dakwah). Surabaya: Al-Ikhlas.

Tirmidzî, Abû 'Îsâ Muhamamad ibn 'Îsâ ibn Saurah ibn Mûsâ al-Dhahhâk (al). 1998. Sunan alTirmidzî, vol. I. Beirut: Dâr al-Gharb al-Islâmî.

Azhari, Fathurrahman. 2014. Qawaid Fiqhiyyah Muamalah. Banjarmasin: Lembaga Pengembangan Kualitas Ummat Banjarmasin.

Fikrî, 'Alî. 1939. al-Mu'âmalât al-Mâddîyah wa al-Adabîyah. Cairo: Mushthafâ al-Bâbî al-Halabî.

Hafiduddin, Didin and Hendri Tanjung. 2008. Manajemen Syariah dalam Praktik. Depok: Gema Insani.

54 Islamic Economics and Partial-Total Religiosity| Muhammad Syarif Hidayatullah 
Hakim, Atang Abd. 2011. Fiqih Perbankan Syariah: Transformasi Fiqih Muamalah ke dalam Peraturan Perundang-undangan. Bandung: Refika Aditama.

Halabî, Aḥmad ibn Muhammad ibn Muhammad Abû al-Walîd Lisân al-Dîn ibn al-Syihnah al-

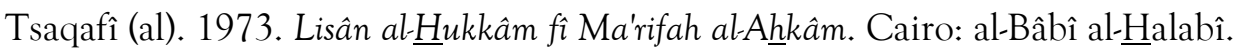

Halim, Abdul. 2008. Politik Hukum Islam di Indonesia: Kajian Posisi Hukum Islam dalam Politik Hukum Pemerintahan Orde Baru dan Era Reformasi. Jakarta: Badan Litbang dan Diklat, Departemen Agama RI.

Hamid, M. Arfin. 2008. Membumikan Ekonomi Syariah di Indonesia (Perspektif Sosioyuridis). Jakarta: eLSAS.

Hasanah, Siti. 2014. "Inovasi Materi Dakwah dari Ibadah ke Muamalah Bagi Ormas Islam untuk Merealisasikan Masyarakat Inklusif di Kota Semarang.” Jurnal Dakwah, 15 (2): 313 333, https://doi.org/10.14421/jd.2014.15205.

Hasyim, Muhammad Ali Haji. 2005. Jihad Ekonomi: Kiat Membangun Kekuatan Bisnis Muslimin. Jakarta: Pustaka al-Kautsar.

Hidayatullah, Muhammad Syarif. 2017. Perbankan Syariah: Pengenalan Fundamental dan Pengembangan Kontemporer. Banjarbaru: Dreamedia.

Irwani, Agus. 2012. “Epistemologi Hukum Ekonomi Islam (Muamalah).” Religia: Jurnal Ilmuilmu Keislaman, 15 (1): 126, https://doi.org/10.28918/religia.v15i1.126.

Ipansyah, Nor, Jalaludin, and Rahman Helmi. 2014. "Fikih Muamalat dalam Majelis Taklim di Kalimantan Selatan.” Tashwir: Jurnal Penelitian Agama dan Sosial Budaya, 2 (3): 87-102.

Mâjah, Abû 'Abd Allâh Muhammad ibn Yazîd al-Qazwinî ibn. 2012. Sunan Ibn Mâjah, vol. III. Beirut: Dâr al-Kutub al-'Ilmîyah.

Mardani. 2011. Ayat-ayat dan Hadis Ekonomi Syariah. Jakarta: Rajawali Pers.

Miles, Matthew B. and A. Michael Hubberman. 1994. Qualitative Data Analysis: An Expanded Sourcebook. London: SAGE Publications.

Muhammad. 2007. Prinsip-prinsip Ekonomi Islam. Yogyakarta: Graha Ilmu.

Munawwir, Ahmad Warson. 1997. Kamus Arab-Indonesia. Surabaya: Pustaka Progresif.

Rijal, Agus. 2013. Utang Halal Utang Haram. Jakarta: Gramedia Pustaka Utama.

Sahroni, Oni. 2019. Fikih Muamalah Kontemporer. Jakarta: Republika.

Syafe'i, Rachmat. 2001. Fiqh Muamalah. Bandung: Pustaka Setia.

Yusuf, Asdar. 2014. "Paradigma Kontemporer Ekonomi Islam (Muh. Abdul Mannan versus Syed Nawab Haedir Naqvi)." Hunafa: Jurnal Studia Islamika, 11 (2): 217, https://doi.org/10.24239/jsi.v11i2.355.215-244.

Zuhailî, Wahbah (al). n.d. al-Fiqh al-Islâmî wa Adillatuh. Damascus: Dâr al-Fikr. 